\title{
Layanan Berbasis Lokasi Hotel Menggunakan Realitas Tertambah
}

\author{
Nur Imansyaha, ${ }^{\mathrm{a},}$, Sri Handani Widiastuti ${ }^{\mathrm{b}}$ \\ ${ }^{\text {ab }}$ Program Studi Teknik Informatika, Sekolah Tinggi Teknologi Bontang
}

Naskah Diterima : 26 September 2017; Diterima Publikasi : 24 Oktober 2017

DOI : 10.21456/vol7iss2pp120-130

\begin{abstract}
Getting information in real time at specific times and locations is especially needed when users have high mobility. But often users are not familiar with the area, so difficulty in finding locations and information. The development of technology for location based services and augmented reality makes it easy to get information from available resources in locations using mobile devices equipped with GPS devices. The research aims to combine hotel location based services and augmented reality in android-based mobile device by manipulating virtual objects into real objects through the camera as input and mobile phone display as output.The integration of hotel location based services and augmented reality is useful for hotel users to be able to search hotel information by directing the camera mobile device in the direction of specific targets to be retrieved information. The output of the system is provided in real time on the mobile device display for the user. Output information provided in the direction of location of the hotel object and information about the object of the hotel.
\end{abstract}

Keywords : Location Based Service; Augmented Reality; GPS; Hotel location

\begin{abstract}
Abstrak
Mendapatkan informasi secara real time pada waktu dan lokasi tertentu sangatlah dibutuhkan terutama ketika para pengguna memiliki mobilitas tinggi. Tetapi sering kali pengguna tidak familiar dengan daerah tersebut, sehingga kesulitan dalam mencari lokasi dan informasi. Berkembangnya teknologi untuk pelayanan berbasis lokasi dan realitas tertambah memberi kemudahan untuk mendapatkan informasi dari sumber daya yang tersedia dilokasi menggunakan mobile device yang dilengkapi perangkat GPS. Penelitian ini bertujuan untuk menggabungkan layanan hotel berbasis lokasi dan realitas tertambah dalam sebuah perangkat mobile phone berbasis android dengan memanipulasi obyek-obyek maya kedalam obyek-obyek nyata melalui kamera sebagai input dan layar mobile phone sebagai output. Intergasi layanan berbasis lokasi hotel dan realitas tertambah berguna bagi pengguna hotel untuk dapat mencari informasi hotel dengan cara mengarahkan kamera mobile device pada arah target tertentu yang akan diambil informasinya. Output dari integrasi sistem ini diberikan secara real time pada layar mobile device pengguna. Output informasi yang diberikan berupa arah lokasi obyek hotel dan informasi mengenai obyek hotel tersebut.
\end{abstract}

Kata kunci: Location Based Service; Augmented Reality; GPS, Lokasi hotel

\section{Pendahuluan}

Perangkat mobile phone dan internet saat ini tidak hanya sebagai alat komunikasi, tetapi juga telah merubah gaya hidup. Sejalan dengan perkembangan teknologi yang terdapat di dalamnya seperti dilengkapinya perangkat GPS (Global Positioning System), kompas digital dan koneksi internet memberikan kemudahan bagi user untuk mengakses informasi di sekitarnya melalui perangkat tersebut.

Layanan berbasis lokasi dalam Bahasa Inggris Location Based Service (LBS) merupakan layanan yang diakses melalui mobile network dan memanfaatkan kemampuan dari lokasi perangkat mobile (Virrantaus, 2001). LBS dapat menghubungkan bisnis-bisnis lokal

*) Penulis korespondensi: n_imansyah@stitek.ac.id yang berada disekitar user sehingga dapat mendorong perkembangan ekonomi melalui akses layanan tersebut, seperti data perkembangan LBS (Tabel 1).

Tabel 1. Data Perkembangan Pengguna LBS Dunia

\begin{tabular}{rrrr}
\hline Tahun & Jumlah Pengguna LBS \\
\hline 2007 & 18.9 Juta & \\
2008 & 41.3 Juta & \\
2009 & 134.0 Juta & \\
2010 & 215.3 Juta & \\
2011 & 329.0 Juta & \\
2012 & 486.0 Juta & \\
\hline \multicolumn{2}{c}{ Tabel 1 } & memperlihatkan bahwa data
\end{tabular}
perkembangan LBS diatas menunjukkan peningkatan pertahunnya pengguna yang memanfatkan layanan tersebut. Pada data aktivitas pengguna LBS 
menunjukkan lebih dari $50 \%$ pengguna pada hal navigasi dan layanan yang dapat diakses disekitar pengguna. LBS dapat menghubungkan antara bisnis dengan konsumennya, dengan menunjukkan lokasi bisnis disekitar konsumen pada saat itu dapat memberikan kemudahan konsumen dalam hal mendapatkan informasi berkaitan dengan obyek bisnis yang dicari.

Realitas tertambah dalam Bahasa Ingrris Augmented reality (AR) adalah variasi dari virtual reality, dimana pengguna dapat melihat dunia nyata dengan obyek-obyek virtual juga disertakan didalamnya, sedangkan pada virtual reality user tidak dapat melihat obyek-obyek nyata didalamnya. Obyekobyek maya diintegrasikan ke dalam lingkungan nyata secara real time seperti halnya pada bidang medis, manufaktur, visualisasi, perencanaan jalur, hiburan dan militer (Ronal dkk., 1997).

Penelitian ini bertujuan untuk menggabungkan LBS dan AR dalam sebuah perangkat mobile phone berbasis android dengan memanipulasi obyek-obyek maya kedalam obyek-obyek nyata melalui kamera sebagai input dan layar mobile phone sebagai output. Dengan menggunakan LBS AR, pengguna dapat melihat arah lokasi obyek hotel di sekitarnya, seperti keadaan gambaran kondisi nyata pada saat itu, sehingga memberikan nilai tambah pada penggunaan user interface untuk LBS. Hal ini disebabkan lebih memberikan rasa alami pada pemakai pada saat menentukan atau mencari suatu obyek melalui AR dari pada hanya dengan melihat peta pada mobile phone (Tuukka dkk., 2010).

\section{Kerangka Teori}

\subsection{Location Based Service}

Perangkat mobile phone dan internet telah berevolusi sebagai alat komunikasi dan gaya hidup. Sejalan dengan perkembangan teknologi yang terdapat didalamnya seperti dilengkapinya perangkat GPS, kompas digital dan koneksi internet pengaksesan suatu informasi dengan memanfaatkan perangkat tersebut dapat disesuaikan dengan area dimana mereka berada, sehingga obyek-obyek yang dicari disekitar user dapat dengan mudah didapatkan, layanan seperti ini dikenal dengan nama Location Based Service (LBS). LBS merupakan layanan yang diakses melalui mobile network dan memanfaatkan kemampuan dari lokasi perangkat mobile (Virrantaus, 2001).

LBS merupakan perpotongan antara tiga teknologi, yaitu teknologi perangkat telekomunikasi dan telepon genggam atau New Information and Communication Technologiies (NICTS), internet dan Sistem Informasi Geografis dengan spasial database (Shiode dkk., 2004), seperti pada Gambar 1.

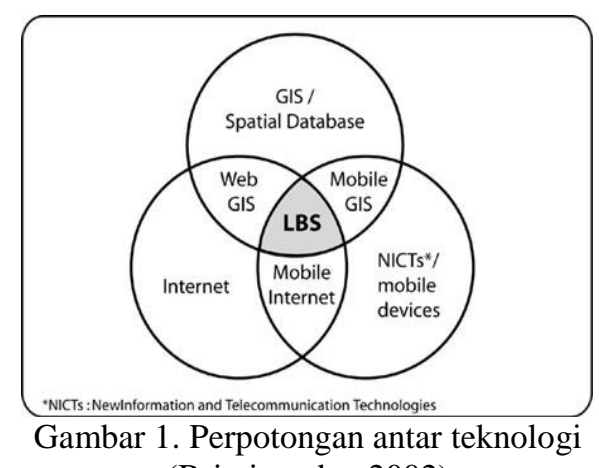

(Brimicombe, 2002)

\subsection{Arsitektur LBS}

LBS merupakan layanan pengiriman data dan informasi yang isinya disesuai dengan permintaan pengguna pada suatu lokasi tertentu. LBS melibatkan berbagai macam teknologi teknologi seperti internet GPS dan teknologi komunikasi wireless (Brimicombe, 2009). Terdapat lima komponen pada arsitektur LBS, yaitu :

a. Data dan content provider, informasi yang disesuaikan dengan permintaan user pada suatu lokasi tertentu pada saat itu.

b. Mobile device, perangkat yang digunakan user untuk mengambil informasi yang dibutuhkan pada lokasi tertentu user saat itu. Mobile device yang digunakan user dilengkapi dengan kemampuan koneksi internet dan dilengkapi perangkat GPS sehingga posisi user pada saat itu dapat diketahui.

c. Network communication, media penghubung antara perangkat komunikasi user dengan server sehingga user dapat melakukan pertukaran data ke LBS provider kemudian LBS provider meresponnya dengan mengirimkan informasi yang diminta user.

d. Positioning system yang memungkinkan posisi pengguna diketahui secara geografis.

e. LBS provider, digunakan untuk melayani permintaan data dari user yang disesuaikan dengan lokasi user saat itu.

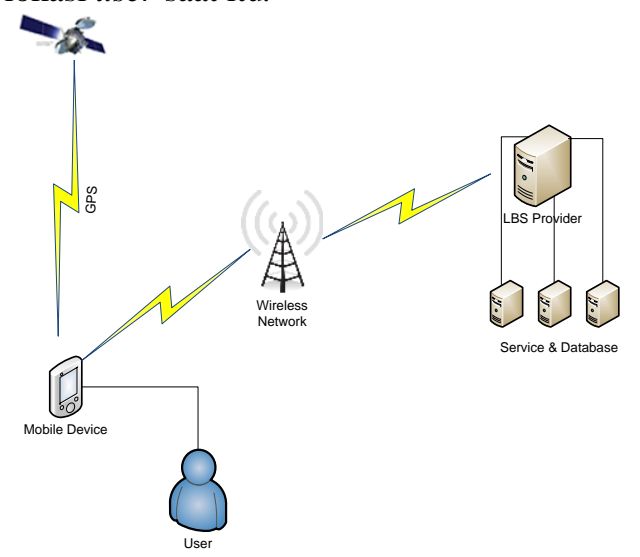

Gambar 2. Arsitektur LBS 
User pada suatu waktu melalui mobile devicenya ingin mendapatkan informasi mengenai obyek hotel yang ada disekitarnya, kemudian user mengaktifkan GPS sehingga posisi user pada saat itu diketahui. Data posisi user dikirimkan ke Positioning System bersamaan dengan permintaan data ke LBS provider melalui Network Communication, sehingga posisi user pada saat itu diketahui dan LBS provider dapat merespon permintaan user sesuai lokasi user pada saat itu.

\subsection{Realitas tertambah}

Istilah virtual reality pertama kali diperkenalkan oleh Jaron Lanier, pendiri VPL Research, yaitu perusahaan dalam bidang virtual reality system. Kemudian istilah tersebut di definisikan sebagai "computer generated, interactif, $3 d$ sehingga seseorang akan hanyut didalamnya" atau istilah lainnya yang masih berhunbungan dengan hal tersebut adalah "artifical reality" oleh Myron Krueger pada tahun 1970.

AR modern pertama di wujudkan pada tahun 1993. Pada tahun 1996 augmented reality memory software dibuat oleh Starner, setahun kemudian MacIntyre dan Seligman membangun Knowledge-based Augmented Reality for Maintenance Assistance (KARMA) sistem AR sebagai alat bantu dalam merawat sebuah mesin printer.

Bidang multimedia, AR menjadikan komoditas pemasaran atau bidang periklanan menjadi lebih interaktif. Konsumen yang akan melihat suatu produk tidak perlu melihat produk nyata, tetapi hanya melihat obyek - obyek dua dimensi maupun obyek- obyek tiga dimensi dalam waktu nyata.

AR adalah variasi dari virtual reality, dimana pengguna dapat melihat dunia nyata dengan obyekobyek virtual juga disertakan didalamnya, sedangkan pada virtual reality user tidak dapat melihat obyekobyek nyata didalamnya. Obyek-obyek maya diintegrasikan ke dalam lingkungan nyata secara real time seperti halnya pada bidang medis, manufaktur, visualisasi, perencanaan jalur, hiburan dan militer (Ronal et al., 1997).

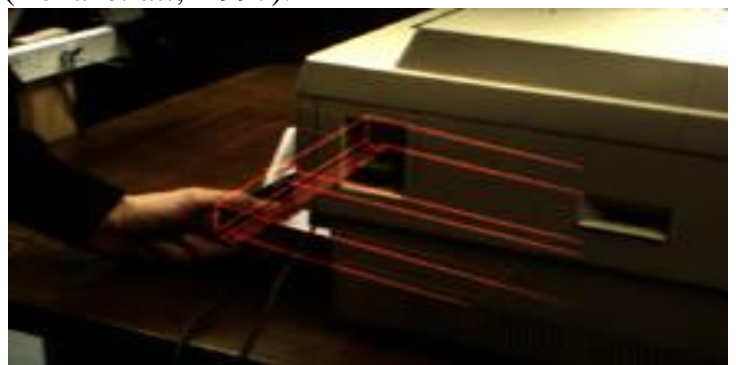

Gambar 3. AR sebagai alat bantu dalam perawatan printer

AR memberikan nilai tambah pada penggunaan user interface untuk layanan Location Based Service Network, hal ini disebabkan lebih memberikan rasa alami pada pemakai pada saat menentukan atau mencari suatu obyek melalui augmented reality dari pada hanya dengan melihat peta pada mobile phone ( Tuukka dkk., 2010).

Dalam realitas tertambah, yang lebih dekat ke sisi kiri, lingkungan bersifat nyata dan benda bersifat maya, sementara dalam augmented virtuality atau virtualitas tertambah, yang lebih dekat ke sisi kanan, lingkungan bersifat maya dan benda bersifat nyata. Realitas tertambah dan virtualitas tertambah digabungkan menjadi mixed reality atau realitas campuran, seperti terlihat berikut,

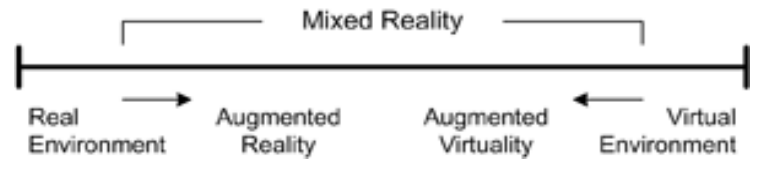

Gambar 4. Virtuality Continuum

Penggunaan AR pada perangkat mobile dilakukan pada proyek urban planning yaitu sebuah metode visual baru yang diformulasikan untuk perencanaan perkotaan, dan berbagai masalah didalamnya. Proses aplikasi algoritma, seperti lokasi obyek virtual pada augmented reality, dianalisis sebagai metode berbasis gambar, selain untuk menghemat lebih banyak waktu, hal itu juga menyajikan hasil yang lebih realistis dan obyektif dibandingkan virtual reality tradisional berbasis grafis (Jie, 2001 ).

AR di bagi menjadi tiga karakteristik, yaitu :

a. Kombinasi antara real dan virtual. AR membutuhkan teknologi layar yang memungkinkan user melihat gambar virtual dan nyata dalam bentuk informasi yang sudah dikombinasi.

b. Interaktif secara real time. AR tergantung pada hubungan antara gambar virtual dan nyata dalam satu hubungan geometris, sehingga proses render antara gambar virtual dan gambar nyata dapat terjadi.

c. Teregistrasi dalam bentuk tiga dimensi. AR

harus berjalan pada interaktif frame rate, karena jika kurang dari interaktif frame rate maka akan informasi yang berjalan secara real time tidak akan berjalan dengan semestinya.

Penelitian sebelumnya telah menunjukan bahwa perkembangan mengenai LBS dan teknologi ARmengalami perubahan dan perkembangan sesuai dengan perkembangan perangkat mobile phone.

Deskripsi dan pemanfaatan teknologi AR pada beberapa bidang antara lain bidang kesehatan, manufaktur, visualisasi, perencanaan, entertaiment and militer yang telah dilakukan ekplorasi sebelumnya (Ronald dkk., 1997).

Seperti halnya penerapan LBS pembelajaran ekologi yang memanfaatkan posisi user pada suatu area tertentu dengan memanfaatkan perangkat mobil, user mendapatkan informasi mengenai materi disekitar daerah ekologi tersebut (Hsiao dkk., 2010), 
antara lain untuk mengenali karakteristik hewan dan tumbuhan pada suatu daerah. Selanjutnya LBS tersebut diterapkan pada perangkat mobile phone yang menggunakan sistem operasi android, tujuannya adalah mendapatkan informasi dan entertainment service melalui mobile device berbasis android dengan memanfaatkan kemampuan posisi geografi dari mobile phone, sedangkan informasi yang didapatkan adalah lokasi dari obyek seperti lokasi bank terdekat atau posisi seseorang pada saat itu (Amit dan Vineet, 2011). Secara spesifik pengaksesan informasi suatu obyek dilakukan untuk mengakses obyek wisata yang terdekat dengan lokasi user pada saat itu dengan memanfaatkan mobile device (ChenHsiung, 2012).

Selanjutnya AR diterapkan pada pembelajaran mengenai solar system (Zahra, 2012). dan untuk mempermudah penulisan program mengenai augmented reality pada bahasa pemrograman maka (Ashok dan Sahitya, 2012) membuat suatu library untuk bahasa pemrograman $\mathrm{C}++$ sehingga penulisan program augmented reality dapat dengan mudah dilakukan.

\subsection{Sudut Azimuth}

Azimut ialah sudut yang dimulai dari utara berputar searah jarum jam ke titik yang dituju. Besarnya azimut adalah $0^{0}-360^{\circ}$. Macam-macam azimut yaitu:

1. Azimut sebenarnya, yaitu sudut yang dibentuk antara utara geografis dengan titik yang dituju.

2. Azimut magnetis, yaitu sudut yang dibentuk antara utara kompas dengan titik yang dituju.

3. Azimut peta, yaitu besar sudut yang dibentuk antara utara peta dengan titik yang dituju.

Gambar mengenai sudut azimuth seperti yang terlihat pada Gambar 5.

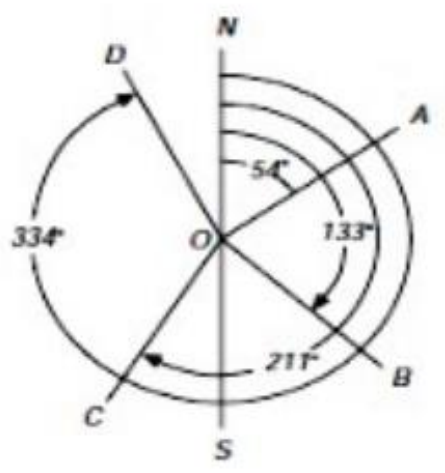

Gambar 5. Sudut Azimuth dari arah utara

\subsection{Bearing (Sudut Arah)}

Bearing adalah sudut yang ukur dari utara maupun selatan berputar searah jarum jam ataupun berlawanan jarum jam ke titik yang dituju. Besarnya bearing antara $0^{0}-90^{0}$ dan ditulis dengan dua huruf arahnya. Back bearing (BBr) adalah besar sudut kebalikan dari fore bearing $(\mathrm{FBr}) . \mathrm{BBr}$ diperoleh dari $\mathrm{FBr}$ dengan cara mengganti huruf awal arah $\mathrm{N}$ menjadi $\mathrm{S}$ (atau $\mathrm{S}$ menjadi N), dan huruf akhir E menjadi W (atau W menjadi E), sedangkan besar sudutnya tetap (Gambar 6).

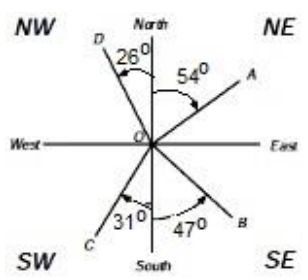

Gambar 6. Bearing dari arah Utara

\section{Metode}

\subsection{Alat Penelitian}

Bahan yang digunakan dalam penelitian adalah data lokasi obyek hotel disemarang diambil 10 lokasi obyek disemarang, content event hotel yang didapat dari hasil pengamatan secara langsung dilapangan dan peta dengan menggunakan Google maps. Perangkat yang digunakan untuk mendesain dan implementasi aplikasi $L B S$ dengan $A R$ terdiri dari perangkat keras dan perangkat lunak. Komputer server, digunakan untuk menempatkan aplikasi $L B S$ dan database $L B S$ yang akan diakses oleh user secara on line, dengan spesifikasi diberikan pada Tabel 1 dan Tabel 2.

Tabel 1. Spesifikasi server hardware

\begin{tabular}{|c|c|}
\hline Hardware & Type \\
\hline Processor & $\begin{array}{l}\text { (1) Intel® Xeon® Processor E5504 } \\
\text { (2.00 GHz, 4MB L3 Cache, } 80 \text { Watts, } \\
\text { DDR3-800) Intel® } 5520 \text { Chipset }\end{array}$ \\
\hline Memory & $\begin{array}{l}4 \text { GB }(2 \times 2 \text { GB) PC3- 10600R } \\
\text { (DDR3-1333) }\end{array}$ \\
\hline Storage & Smart Array P410i/Zero Memory \\
\hline Controler & $\begin{array}{l}\text { Controller (RAID 0/1/1+0) Available } \\
\text { upgrades: } 256 \mathrm{MB}, 512 \mathrm{MB} \text { with } \\
\text { BBWC, Battery kit upgrade (for } \\
\text { BBWC), and Smart Array Advanced } \\
\text { Pack (SAAP) }\end{array}$ \\
\hline Hard Drive & $\begin{array}{l}11 \times \text { HP 146GB 10K SAS } 2.5 \text { DP } \\
\text { HDD }\end{array}$ \\
\hline $\begin{array}{l}\text { Optical } \\
\text { Drave }\end{array}$ & 12.7mm SATA DVD-RW kit \\
\hline Network & 1 x NC382i Dual Port Multifunction \\
\hline Control & $\begin{array}{l}\text { Gigabit Server Adapter (two ports } \\
\text { total) with TCP/IP Offload Engine, } \\
\text { including support for Accelerated } \\
\text { iSCSI }\end{array}$ \\
\hline Expansion & Two PCI-Express Gen 2 expansion \\
\hline Slot & $\begin{array}{l}\text { slots: (1) full-length, full-height slot; } \\
\text { (1) low-profile slot Optional PCI-X } \\
\text { Riser expansion slot }\end{array}$ \\
\hline Port & $\begin{array}{l}\text { USB 2.0 Support } 4 \text { Total: (1) front, (1) } \\
\text { internal and (2) rear accessible ports1 } \\
\text { internal Secure Digital (SD) slot }\end{array}$ \\
\hline Power & Dual Common Slot Bays for High \\
\hline Sources & $\begin{array}{l}\text { Efficiency, Right Sized, Hot plug and } \\
\text { Redundant Power options , 460W CS } \\
\text { HE Gold Power Supply }\end{array}$ \\
\hline Fans & $\begin{array}{l}3 \text { total ( } 3 \text { fans in } 1 \text { Processor Models, } \\
1 \text { additional fans with } 2 \text { Processor } \\
\text { Model) redundancy standard }\end{array}$ \\
\hline $\begin{array}{l}\text { Operating } \\
\text { System }\end{array}$ & Windows server \\
\hline
\end{tabular}


Mobile phone, digunakan untuk menempatkan aplikasi $L B S$ dengan menggunakan $A R$.

Tabel 2. Spesifikasi android hardware

\begin{tabular}{ll}
\hline Hardware & Type \\
\hline Processor & Dual-core 1.5 GHz \\
Memory & 16 GB, 1 GB RAM \\
Kamera & 12 MP, 4000x3000 pixels, \\
& autofocus, LED flash \\
Graphic Processor Unit & Adreno 220 \\
Sensor & Accelerometer, gyro, \\
& proximity, compass \\
GPS & Build in \\
Operating System & Android OS, v2.3 \\
& (Gingerbread), / v4.0 (Ice \\
& Cream Sandwich) \\
Network & GSM, 3G, HSDPA \\
\hline
\end{tabular}

Perangkat lunak yang digunakan dalam perancangan terdiri dari beberapa jenis aplikasi :

a. Aplikasi pengolah desain : desain sistem yang digunakan adalah easycase ver 4.2 untuk membuat desain pemodelan sistem.

b. Aplikasi pembangun sistem bahasa pemrograman merupakan aplikasi yang digunakan untuk mengimplementasikan perancangan ke dalam program yang siap digunakan, bahasa pemrograman yang digunakan adalah JAVA untuk android, PHP dan JavaScript.

c. Aplikasi web server : yaitu aplikasi yang berfungsi sebagai server dan pengolah database. Aplikasi yang digunakan adalah XAMPP, aplikasi ini bersifat open source, mendukung dinamic web, dan telah mencakup didalamnya adalah HTTP Server dan MySQL database.

\subsection{Pengumpulan Data}

Mengumpulkan data lokasi hotel dan data content hotel yang ada di Semarang. Beberapa metode pengumpulan data yang digunakan dalam penelitian dengan engumpulkan data dan informasi yang didapat secara langsung di lapangan seperti : nama obyek hotel dan posisi hotel-hotel serta content event obyek hotel yang ada yang ada di Semarang. Sedangkan spesifikasi android yang digunakan user untuk menjalankan aplikasi ditunjang oleh perangkat, antara lain : Koneksi internet, koneksi internet digunakan untuk mengambil data obyek yang tersimpan dalam database. Kompas, perangkat kompas digunakan untuk menentukan arah antara user dengan obyek. GPS, perangkat ini digunakan untuk mengetahui posisi user secara real time sehingga dapat digunakan untuk menunjang penentuan posisi-posisi obyek disekitar user. Kamera, perangkat ini digunakan untuk mengambil image real time sebagai penunjang proses augmented reality.

\subsection{Perancangan Sistem}

Terdapat dua hal yang dilakukan untuk membangun LBS obyek hotel dengan menggunakan AR. Pertama, membangun Map Server yang berfungsi sebagai penyimpan data spasial peta, dan sebagai media editor peta. Kedua, embangun aplikasi AR berbasis android yang diaplikasikan pada perangkat mobile phone. Untuk implementasinya seperti yang terlihat pada arsitektur LBS AR seperti pada Gambar 7.

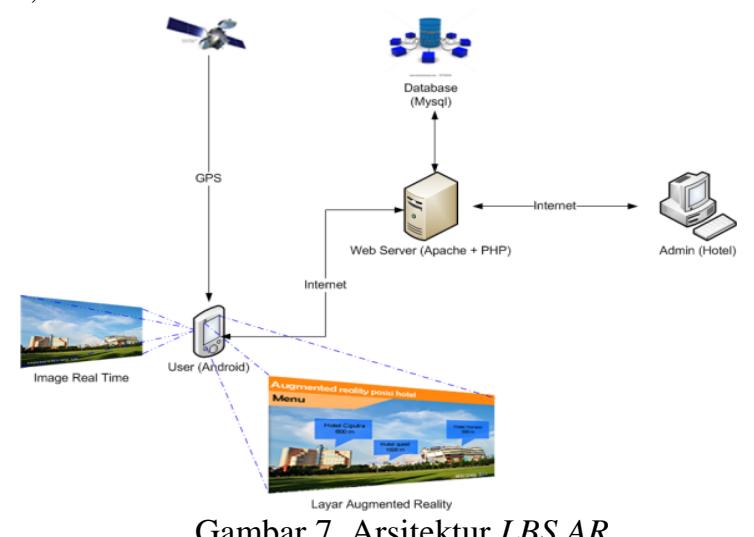

Seperti yang terlihat pada gambar 3.1 diatas user menggunakan perangkat mobile phone android untuk mengambil data obyek pada database melalui koneksi internet, selanjutnya data tersebut diseleksi berdasarkan jarak antara obyek dengan user dengan posisi user pada saat itu didapatkan dari perangkat GPS pada perangkat mobile phone.

Langkah berikutnya user mengambil image real time melalui kamera dengan cara mengarahkan kamera mobile phone tersebut ke arah di sekitar user, selanjutnya mobile phone akan memproses dengan cara menggabungkan image real time dengan data obyek menjadi augmented reality pada layar mobile phone.

Berikut diberikan proses perancangan sistem pada $L B S A R$. Diagram konteks merupakan diagram tingkat atas yang penggambaran aliran data keluar atau data masuk dari proses menuju entiti atau sebaliknya tidak digambarkan secara detail. Diagram konteks digunakan untuk menggambarkan proses request dan respond pada $L B S A R$ hotel seperti pada Gambar 8 .

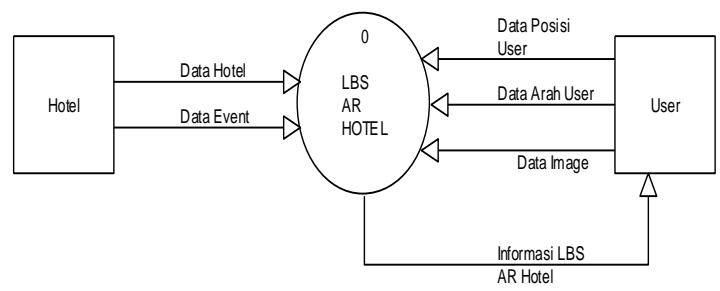

Gambar 8. Diagram konteks $L B S A R$

Pada Gambar 8 menjelaskan bahwa hotel melakukan input data hotel dan data content event, untuk data hotel terdiri dari data posisi hotel meliputi terdiri latitude dan longitude dan data event meliputi data content dari hotel tersebut, kemudian oleh sistem data tersebut disimpan dalam database.

Pada bagian user melakukan input data arah user menghadap terhadap obyek dan data posisi user 
secara realtime dan pada waktu yang sama user juga melakukan data image secara realtime, selanjutnya oleh sistem $L B S A R$ hotel data dari hotel maupun user diproses sehingga menghasilkan informasi $L B S A R$ hotel yang digunakan oleh user.

DFD digunakan untuk menjelaskan secara rinci alir data yang ada pada diagram konteks, DFD dibentuk setelah diagram konteks dibuat, sehingga gambaran alir data dari sistem $L B S A R$ hotel terlihat lebih rinci seperti pada Gambar 9.

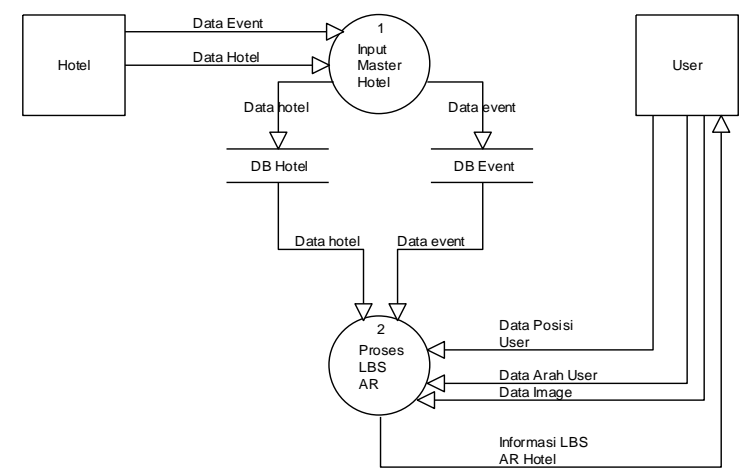

Gambar 9. DFD level 0 LBS AR Hotel

Proses input, admin melakukan input data hotel yang terdiri dari titik lokasi hotel kemudian disimpan dalam tabel dbhotel dan data content event disimpan dalam tabel dbevent.

Proses LBS AR hotel, pada bagian ini sistem mengambil data titik lokasi hotel dari tabel dbhotel kemudian sistem mendapatkan data arah user, data posisi user dan data image dari user sehingga dapat di ketahui posisi obyek-obyek hotel sesuai dengan arah user menghadap. Data event diambil oleh sistem dari tabel dbevent yang berfungsi memberikan data content kepada user dari obyek-obyek hotel, dari pengumpulan data kemudian sistem melakukan penggabungan antara data image realtime dengan data content $L B S A R$ kemudian dikirimkan ke user sebagai informasi $L B S A R$ hotel.

Proses $L B S A R$, pada tahap ini proses mengabil data posisi pengguna, arah pengguna dan data image real selanjutnya hasil proses tersebut menjadi informasi LBS AR Hotel untuk pengguna. Untuk penyimpanan data $L B S A R$ hotel menggunakan dua tabel database antara lain adalah sebagai berikut:

a. Tabel Hotel. Tabel Hotel, digunakan untuk menyimpan data hotel didalamnya terdapat field, kd_hotel, nm_hotel, alamat, kota, email, url, user dan password.

b. Tabel event. Tabel event, digunakan untuk menyimpan data event hotel, didalamnya terdapat field kd_event, lat, lng, sts dan kd_hotel.

Gambar 10 memperlihatkan relasi antar tabel LBS $A R$ hotel.

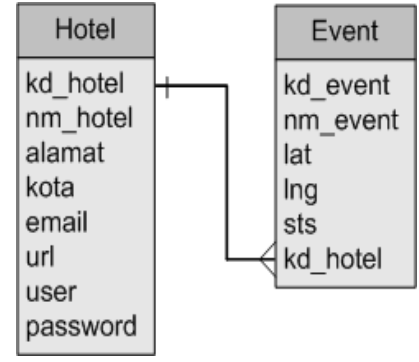

Gambar 10. Relasi antar tabel database $L B S$ AR hotel

Relasi antara merchant dengan event menggunakan one to many, satu Hotel mempunyai beberapa event.

\subsection{Tahap Membangun Map Server}

Map server digunakan untuk yang menyediakan layanan akses kepada pengguna berhubungan penyimpanan data spasial pada database. Web server yang dibangun menggunakan Apache web server, berikut bagian-bagian dari web server.

1. Pembuatan peta.

Peta kota semarang di ambil dari Google maps, pembuatan peta ini digunakan untuk menandai lokasi obyek hotel pada pada suatu area sehingga posisi latitude dan longitude lokasi titik obyek dapat diketahui. Pembuatan peta dengan menggunakan Google maps API 3 seperti pada Gambar 11.

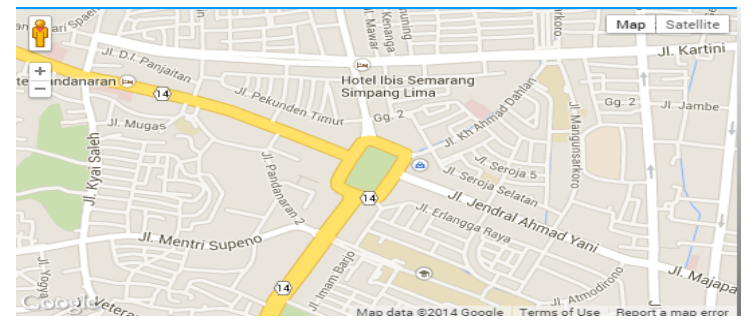

Gambar 11. Gambar peta dari Googlemap

2. Pembuatan titik koordinat lokasi obyek.

Titik koordinat obyek dan titik koordinat content event pada peta dilakukan dengan memberikan tanda pada peta sebagai input koordinat obyek hotel yang selanjutnya disimpan dalam database.

3. Pembuatan input content event obyek hotel.

Input Content event hotel dilakukan setelah dilakukan penandaan pada lokasi titik obyek hotel yang kemudian dilakukan edit data content event selanjutnya di simpan dalam database.

4. Pembuatan database untuk penyimpanan data lokasi obyek dan content event obyek hotel menggunakan database MySQL ver 5.5.

Penentuan titik lokasi obyek hotel dilakukan dengan menggunakan Google maps secara online, yaitu dengan cara memberikan tanda pada peta mengenai lokasi obyek hotel sehingga di dapatkan nilai latitude dan longitude yang kemudian disimpan dalam database. Pada bagian ini juga dimasukkan data content event yang berhubungan dengan hotel tersebut seperti pada Gambar 12. 


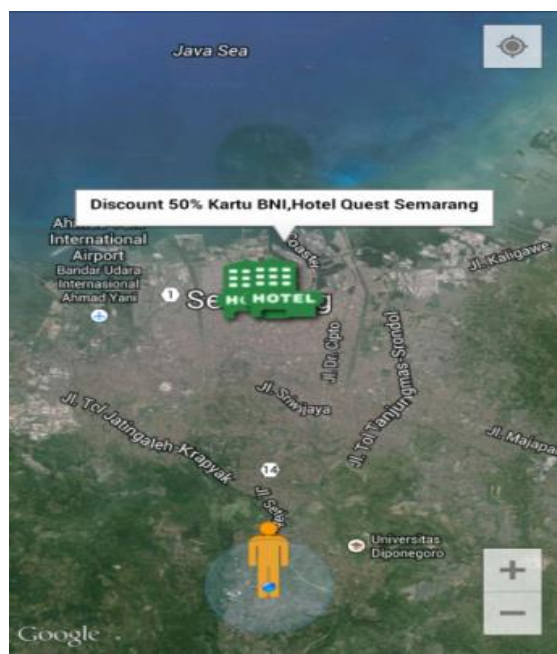

Gambar 12. Data obyek peta dan content event

\subsection{Membangun LBS AR pada Android.}

Proses pembuatan aplikasi $L B S A R$ berdasarkan pada algoritma $L B S A R$ seperti pada Gambar 13.

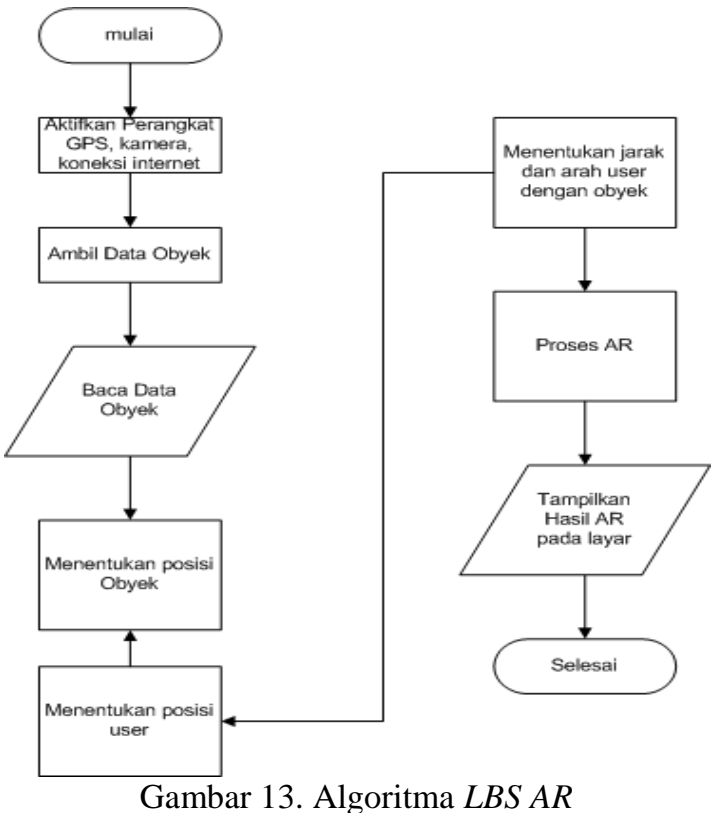

Berdasarkan algoritma diatas maka di lakukan beberapa langkah seperti berikut :

1. Load Data Spasial

Data Spasial diperoleh dari map server yang sebelumnya telah tersimpan dalam database.

2. Pengambilan data titik lokasi pengguna.

Data posisi Pengguna dilakukan dengan cara mengaktifkan perangkat GPS pada mobile phone pengguna sehingga didapat nilai latitude dan longitude lokasi pengguna secara real time, seperti pada Gambar 14.

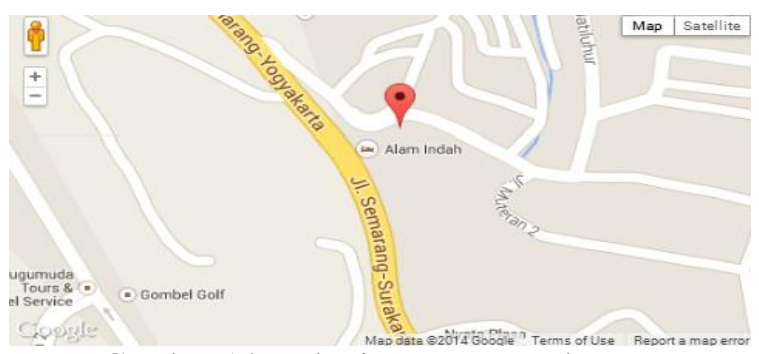

Gambar 14. Lokasi pengguna pada peta

3. Data arah pengguna terhadap obyek hotel

Data arah pengguna secara realtime didapat dari mobile phone dengan membaca nilai accelerometers dan magneticfield pada perangkat mobile phone sehingga pada saat pengguna menggunakan perangkat tersebut dan menghadap pada arah tertentu maka data arah pengguna tersebut diambil seperti pada Gambar 15.

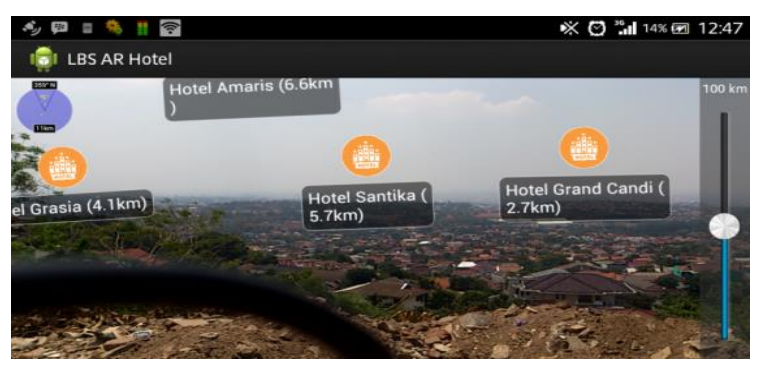

Gambar 15. Arah pengguna terhadap arah hotel

Seperti yang terlihat pada Gambar 15, data arah user diambil dengan arah menghadap utara dengan nilai derajat $359^{\circ}$.

Pada bagian ini dilakukan perhitungan sudut antara user dengan obyek untuk mengetahui arah posisi obyek-obyek akan ditampilkan pada layar mobile phone. Dalam sistem navigasi terdapat istilah azimuth yaitu sudut antara utara magnetis (nol derajat) dengan titik/sasaran pengguna tuju relatif terhadap sudut utara. Sudut azimuth pada masing-masing titik dihitung berdasarkan sudut arc tangent antara perbedaan latitude dengan lokasi pengguna dibagi dengan perbedaan longitude seperti pada Gambar 16.

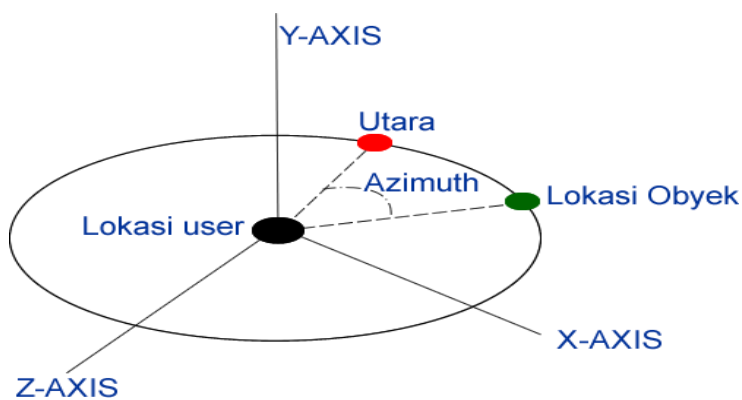

Gambar 16. Ilustrasi sudut antara user dengan obyek 
Setelah mendapatkan sudut azimuth pada setiap titik langkah berikutnya adalah menemukan lokasi horizontal pada layar untuk menampilkan titik-titik lokasi obyek. Sudut azimuth di-update terus menerus sehingga bisa mewakili posisi imajiner di depan pengguna saat pengguna melakukan rotasi atau memutar layar handphone kekiri atau kekanan.

a. Perhitungan sudut inklinasi

Sudut inklinasi merupakan sudut vertikal yang dibentuk antara titik tempat pengguna menggunakan aplikasi dengan titik lokasi obyek. Dengan menggunakan GPS jarak antara user dengan titik obyek dapat diketahui sehingga titik ketinggian suatu lokasi dapat diketahui berdasarkan sudut dari titik user. Setelah didapatkan ketinggian masing-masing titik langkah berikutnya yaitu menentukan sudut vertikal antara 2 titik tersebut dengan rumus trigonomteri.

Sensor akselerometer melakukan pembacaan terhadap orientasi handphone yang dipegang pengguna. Jika pengguna memegang dengan posisi layar menghadap depan dan rata dengan tanah maka ikon obyek akan ditampilkan sejajar terhadap horison. Namun jika pengguna memegang device pada posisi 45 derajat kebawah maka ikon obyek muncul pada layar bagian atas. Sumbu-X dalam representasi dunia nyata adalah garis horizontal, sumbu-Y merupakan garis vertikal dan sumbu-Z mengarah kearah depan layar sedangkan area di belakang layar memiliki nilai $\mathrm{Z}$ negatif seperti pada Gambar 17.

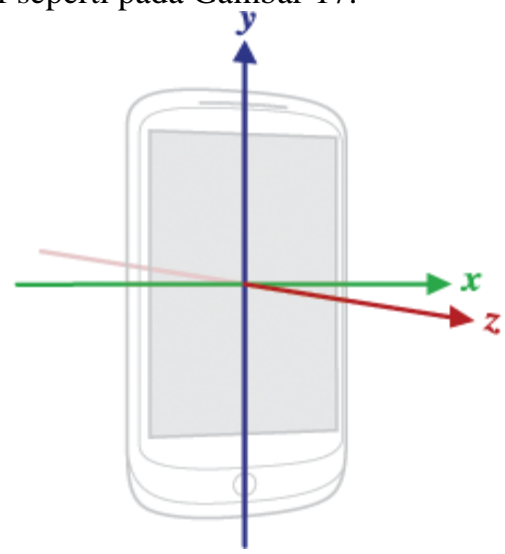

Gambar 17. Arah aksis akselerometer pada device android.

Sensor akselerometer pada android menangkap 3 buah nilai dalam satuan $(\mathrm{m} / \mathrm{s} 2)$

Nilai[0] : nilai akselerometer pada sumbu $\mathrm{x}$

Nilai[1] : nilai akselerometer pada sumbu y

Nilai[2] : nilai akselerometer pada sumbu z

Sensor akselerometer menghitung akselerasi yang dikenakan pada device.

4. Data image real time

Data image secara real time diperoleh dari kamera pada mobile phone sehingga representasi dari dunia nyata yang selanjutnya digunakan untuk proses $A R$ seperti pada Gambar 18.

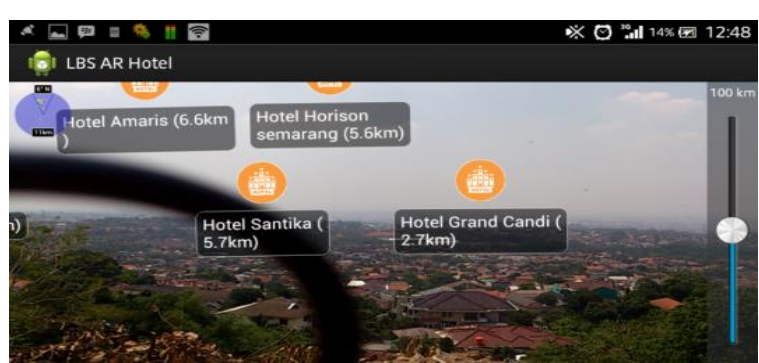

Gambar 18. Image real time pada $A R$ melalui kamera mobile pone

5. Proses Pembentukan Augmented Reality

Pada bagian ini dilakukan penggabungan image real time dari kamera mobile phone dengan obyek hotel yang dilambangkan dengan ikon serta content event didalamnya, kemudian ditampilkan pada layar mobile phone seperti pada Gambar 19.

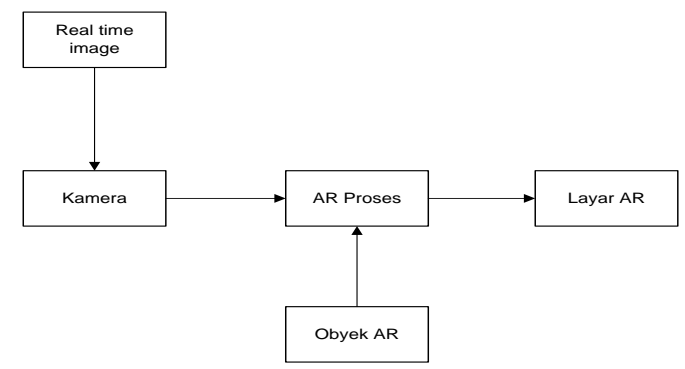

Gambar 19. Proses Pembentukan Augmented reality

Pada Gambar 10, image real time diambil melalui kamera mobile phone dengan menggunakan fungsi : camScreen $=$ new CameraSurface $($ this $)$; setContentView(camScreen);

Proses selanjutnya adalah meletakkan gambar ikon pada layar mobile phone seperti pada Gambar 20.

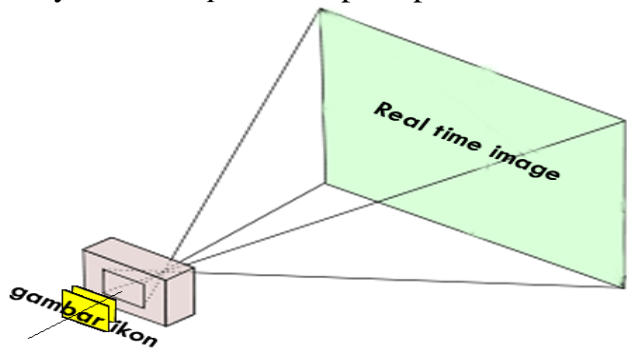

Gambar 20. Penggabungan image pada AR

Dengan menggunakan fungsi draw pada android mobile phone penggabungan realtime image yang ditangkap melalui kamera dengan data obyek yang digambarkan dengan ikon dilakukan. Peletakan gambar ikon pada layar mobile phone sesuai dengan lokasi obyek berada dengan arah user menghadap , untuk itu dilakukan konversi posisi yang semula sebagai koordinat latitude dan longitude pada peta menjadi koordinat $(\mathrm{x}, \mathrm{y})$ pada layar mobile phone, dengan cara menghitung nilai sudut antara user dengan obyek. 


\section{Hasil dan Pembahasan}

\subsection{Implementasi aplikasi pada Server}

Aplikasi Server digunakan untuk mengolah data spasial dan non-spasial antara lain menambah, mengubah, menghapus dan menampilkan atau merepresentasikan data spasial dari database ke dalam peta digital. Aplikasi Server hanya dapat diakses oleh pengguna administrator yang memiliki hak akses masuk kedalam aplikasi.

1. Halaman menu utama map editor

Berikut adalah halaman utama map editor LBS AR, terdapat fasilitas login bagi user seperti pada Gambar 21.

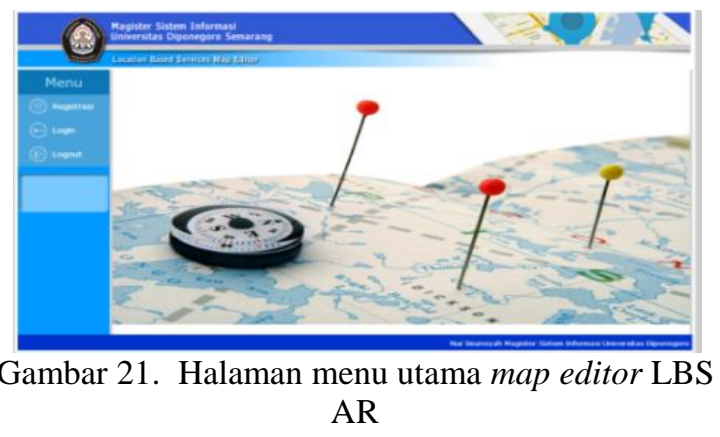

2. Halaman Registrasi

Pada halaman ini berfungsi untuk mengolah data merchant seperti pada Gambar 22.

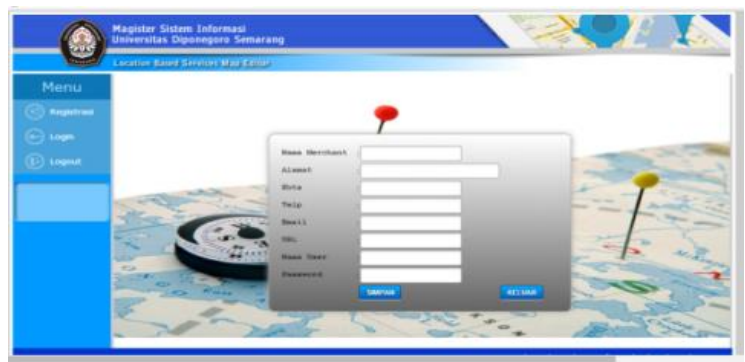

Gambar 22. Halaman menu utama map editor

$$
\text { LBS AR }
$$

\section{Halaman Login}

Halaman login dipergunakan untuk proses verifikasi status user sebagai administrator atau merchant seperti pada Gambar 23.

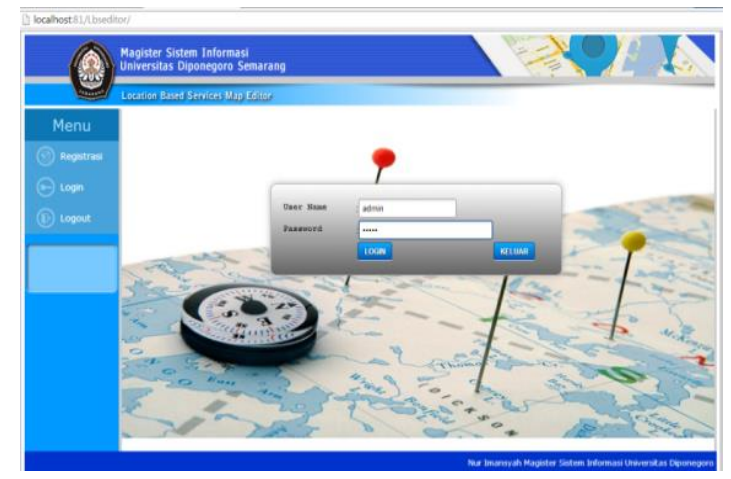

Gambar 23. Halaman login map editor LBS AR

\section{Halaman Administrator}

Halaman admininistrator berfungsi untuk menambah, edit, menghapus data merchant seperti pada Gambar 24.

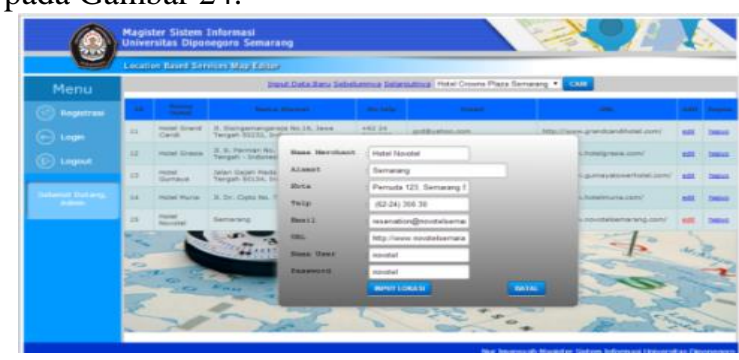

Gambar 24. Halaman login map editor LBS AR

5. Halaman Merchant

Halaman Merchant digunakan untuk update data merchant dan data event seperti pada Gambar 25.

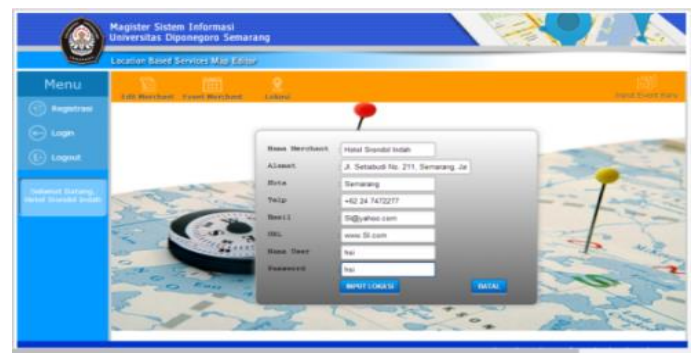

Gambar 25. Halaman merchant LBS AR

6. Мепи logout

Menu logout digunakan untuk keluar dari halaman user aktif pada saat itu, kemudian akan kembali ke menu utama.

\subsection{Implementasi aplikasi pada mobile phone}

Aplikasi mobile digunakan pengguna untuk mengetahui informasi lokasi hotel yang berada disekitar user serta data content event yang ada dan disajikan dalam bentuk AR.

Aplikasi akan memeriksa koneksi internet untuk yang digunakan untuk download data non spasial dari server, Selanjutnya dilakukan pemeriksaan terhadap perangkat GPS Setelah dilakukan pemeriksaan terhadap koneksi internet dan perangkat GPS, maka akan muncul menu pada perangkat mobile :

1. Menu Utama

Menu utama merupakan halaman fasilitas dari aplikasi LBS AR hotel, fasilitas tersebut antara lain : sembunyikan radar, sembunyikan zoom bar, tampilkan peta, AR Hotel, AR Event dan Exit seperti pada Gambar 26

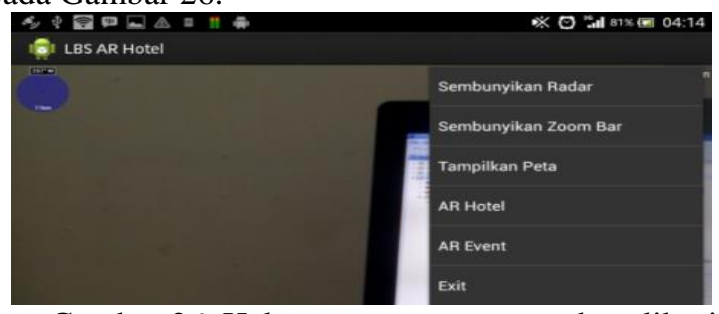

Gambar 26. Halaman menu utama pada aplikasi LBS AR 


\section{Load Data}

Load data adalah proses download data dari server database ke dalam aplikasi LBS AR seperti pada Gambar 27.

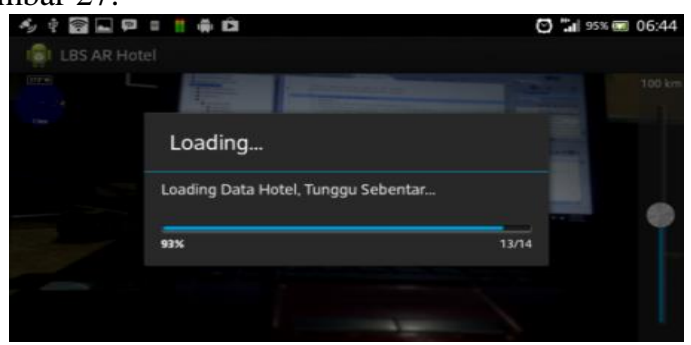

Gambar 27. Proses pengambilan data hotel pada aplikasi $L B S A R$

\section{Halaman LBS AR}

Pada bagian ini adalah tampilan dari LBS AR, informasi ditampilkan dalam bentuk AR seperti pada Gambar 28.

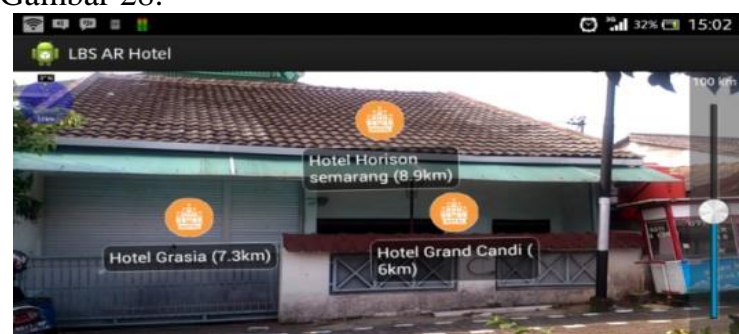

Gambar 28. Halaman LBS AR

Pada Gambar 28 terdapat ikon yang merupakan informasi arah obyek hotel berada, sedangkan teks dibawahnya merupakan identitas dari obyek tersebut dengan informasi jarak antara pengguna dengan obyek tersebut.

4. Halaman webview

Halaman webview berfungsi untuk menampilkan halaman web obyek hotel pada perangkat mobile. Output ditampilkan sebagai obyek AR dengan failitas link, sehingga cutomer dapat langsung terhubung dengan halaman web dari obyek hotel seperti pada Gambar 29.

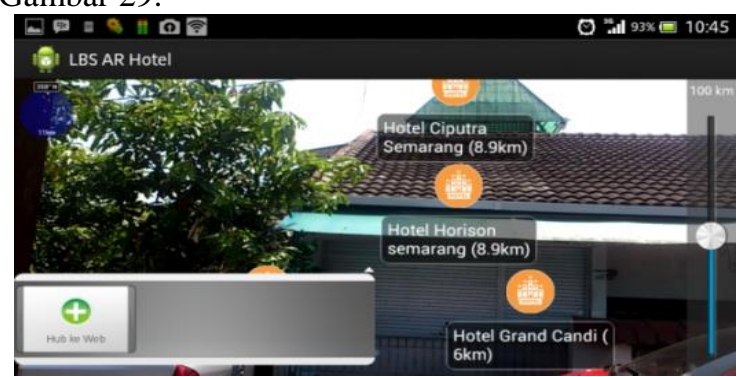

Gambar 29. Halaman weblink pada LBS AR

\section{Halaman peta}

Pada halaman ini ditampilkan dalam bentuk peta yang lokasinya sesuai dengan posisi pengguna pada saat itu dan obyek-obyek yang ada disekitar pengguna seperti pada Gambar 30.

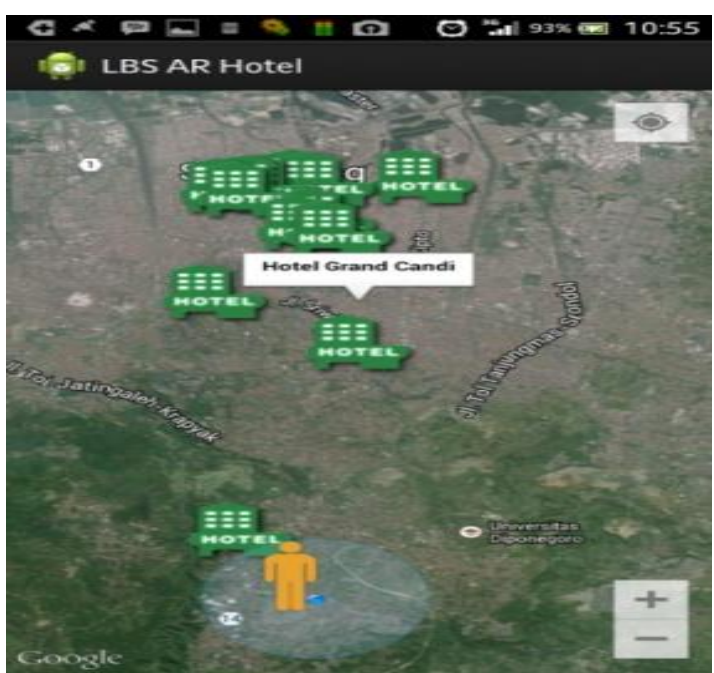

Gambar 30. Halaman peta pada LBS AR

Seperti yang terlihat pada gambar 28 pengguna dan obyek hotel di gambarkan dengan ikon yang posisinya pada peta sesuai dengan posisi pengguna pada saat itu, informasi mengenai obyek didapatkan dengan cara pilih obyek hotel yang akan diambil informasinya sehingga memunculkan kotak informasi nama dari obyek hotel tersebut.

\subsection{Pengujian}

Pada pembuatan LBS AR hotel ini dilakukan Black Box Testing tujuannya untuk membuktikan bahwa sistem dapat berjalan dengan baik dan pengujian hanya difokuskan pada fungsi-fungsi perangkat lunak.

\section{Kesimpulan}

Layanan berbasis lokasi (LBS) Hotel menggunakan realitas tertambah (AR) merupakan sistem layanan informasi real time yang dapat diakses dengan perangkat mobile phone Android mengenai lokasi obyek hotel beserta event content yang informasinya disesuaikan dengan informasi yang tersedia pada suatu area dimana posisi user pada saat itu berada.

LBS AR aplikasi mampu memberikan informasi lokasi suatu obyek berdasarkan arah pengguna dalam berinteraksi dengan melalui perangkat handphone yang digunakan output dari perangkat tersebut suatu informasi yang dipadukan dengan image nyata secara realtime melalui layar pada perangkat handphone yang digunakan pengguna. Dengan memanfaatkan posisi GPS yang akurat dan pengolah image yang tepat akan memberikan informasi kepada user keberadaan obyek secara tepat. 


\section{Daftar Pustaka}

Amit, K., Vineet, K., 2011. Location Based Services using Android Mobile Operating System, International Journal of Advances in Engineering \& Technology, 1-7.

Ashok, K.M., SahityaPriyadharshini, K., 2012. A Survey of ARToolkitBased Augmented RealityApplications, Journal of Computer Applications, 261-263

Brimicombe, A.J., 2002. Where are the frontiers now?, In: Proceedings GIS 2002., 33-45.

Chen-Hsiung, C., 2012. Location-Based Service For Tourism, International Journal of Multidisciplinary Management Studies 2(2), 1-21.

Hsiao, H., 2010. Location Based Services for Outdoor Ecological Learning System: Design and Implementation, Journal of Educational Technology \& Society 13 (4), 98-111.
Jie, S., 2001. Urban Planning Using Augmented Reality, Journal of Urban Planning \& Development 127(3), 118.8.

Ronald, T.A., 1997. A Survey of Augmented Reality, Presence: Teleoperators and Virtual Environments, 355-385.

Shiode, N., Li, C., Batty, M, Longley, PA., D Maguire, D., 2004. The Impact and penetration of Location Based Service, Telegeoinformatics, 349366.

Tuukka, T., Tino, P., Juha, R., 2010. Mobile AR Requirements for Location Based Social Networks, International Journal of Virtual Reality 9 (4), 67-78.

Zahra, M., 2012. Innovative Learning of Solar System using Augmented Reality for Primary School Children, University of Nottingham

Virrantaus, K., 2001. Developing GIS-supported location-based services, Web Information Systems Engineering, 66-75. 